\title{
Studying the Effect of Market Competition on the Auditing Fees and the Operational Costs Efficiency as the Agency Costs Indexes
}

\author{
Hashem VALIPOUR ${ }^{1}$ \\ Javad MORADI ${ }^{2}$ \\ Ehsan HESHMATZADE ${ }^{3}$
}

\author{
${ }^{1,3}$ Accounting Department, Islamic Azad University, Firoozabad Branch, Firoozabad, Iran, \\ E-mail: h.valipour@gmail.com, ${ }^{3}$ E-mail: ehsan.h749@yahoo.com (Corresponding author) \\ ${ }^{2}$ Accounting Department, Shiraz University, Shiraz, Iran, ${ }^{2}$ E-mail: imoradi@yahoo.com
}

\begin{abstract}
In the study the effect of market competition on the agency costs was examined in the companies listed in Tehran stock exchange; hence, 56 companies were examined in 2005-2010. The selected approach benefits from Panel Data to test the hypotheses and the natural logarithm of auditing fees and operational costs ratio were considered to calculate the agency costs. The findings indicate that there is significant relation between the competition effect in the product market and agency costs when the confidence rate is 95 percent; also the findings indicate that the debt rate has no significant effect on the agency costs.
\end{abstract}

Key words Agency theory, agency costs, auditing fees, market competition

\section{Introduction}

Nowadays the auditing role is very essential and unavoidable in reinforcing the respondence and accounts description through requesting them and strengthening trust in fiscal report in line with public interest. In recent years on the tack of some companies and auditing institutions scandal there was some evidence indicating more requests for audit quality improvement and some considerable changes in accounting in the light of separation possession from management in companies. In past the possessors were the managers of the firm at the same time and we saw them in the same position and on the other hand, the possessors controlled all operations led to increase the company value. Technologic progress and increasing need concerning capital led to create great capital markets and then possession separated from management; the main problem was to find the place of the control in the transaction to keep previous condition; on the other hand, how the control should be done? Is it possible to control the director's behaviour? Does the director move in line with the shareholder? By virtue of above statements agency means 'The power to be transferred to another one (Director) to take decision concerning financial and economical sources distribution or do service(s) by someone (Possessor) by virtue of a defined contract (Namazi, 2005).

Agency relation is when the possessors appoint the directors as representatives (Agents) and transfer considerable powers and responsibilities to them; such work division may increase the economic institution efficiency and effect though it needs complete directors' trust in the agents. In the simple agency model the data asymmetry and interest contradiction are the most important factors for incomplete trust which may lead to organize some mechanisms maximizing the interests' unity. The main hypothesis in the agency theory is on the basis of all the company beneficiaries' interest in maximizing their own economic interests; so on this basis it is possible to suppose the economic institution as the geometric intersection of which each point originated from Greek thought and logic in a way that by virtue of Shruder's and Clark's view the main question is 'How much is the profit from doing a special work expected by everyone? 'The problems between 
the directors and possessors appear when the decisions taken by the directors increase their own interests but do not increase the possessors' or shareholders' ones. In addition to the relation between the directors and possessors the relation between directors and auditors and the relation between the auditors and possessors may include some signification of agency.

In their studies Jensen and Meckling (1976) concluded that the agency costs are not correlated with the competition in the product market. Also Weetman et al. found that the auditing fees have reverse relation with the competition in the product market. By virtue of similar studies present study is to examine the relation between the competition in the product market and agency costs. Also the auditing services and operational costs efficiency have been considered as some aspect of the agency costs.

\section{Literature Review}

\subsection{Auditing fees}

Pricing auditing services is one of the interesting subjects for many auditing researchers and until now many studies have been done in this regard. If employer and auditor know such factors, they will be useful for them. The auditing cost is a considerable number for many employers. Although great companies with high sale and liquidity or some governmental companies may pay easily such amount, for many small firms or ones with bad financial condition the amount may be a high payable amount. In sum, it is possible to decrease the amount and make it more bearable by knowing the factors effective on the auditing fees, negotiation and discussion on the amount and controlling the factors in the organization.

The auditor's economic benefits are realized through paying fees according to the contract concluded with the employers. The auditors use different factors to price the auditing services and many studies have been done in relation to know and assess the factors (Sunder, 1997).

When the sources available to the management increase the beneficiaries and relation with company increase, too and it leads to contradictory interests so the beneficiaries should sustain the agency costs to harmonize their interests with others' and decrease the damages from the contradiction (Stein and Simunic, 1996).

Having studied auditing services pricing it became known that the factors effective on the auditing fees were defined by the factors effective on the auditing work size as a motive for auditing services fees. All auditors expect to stay in the market and have more exclusive profit in the auditing services market (Gul et al, 1998). During auditing services pricing study the factors effective on auditing services fees are examined by the effect of the factors on three factors describing the unit namely risk, size and operation complexity.

The auditing fees are announced in the fiscal reports and relates to previous year fiscal statements. So if great book tax differences indicate the validity of low profit quality and the auditor needs additional approaches to form the viewpoint, the additional auditing work for that fiscal statement is in relation to the fiscal year even if the approaches of the end of the year would be executed in some months of the following year. Even if the fees are negotiated at the first of the auditing, there is an opportunity for the auditor to receive more fees than what expected at the end of the year (Harlow and Howe, 1993).

The auditing fees are high when the book tax differences are high and negative and vice versa because the positive difference may include management and high tax potentials (Hanlon and Mills, 2009).

The auditing fees have reverse relation with the production market competition. The relation between the production market competition and the auditing fees was examined as a sample of the agency cost (Weetman, Leventis, Caramanis, 2011). By virtue of the findings the auditing fees appears where the competitive pressures decrease the shareholders' need to sustain the costs concerning supervising agencies.

\subsection{Operational costs efficiency}

In present study the dependent variable is agency costs and we use an efficiency ratio namely the ratio of operational costs to yearly sale as the agency costs scale. The efficiency ratios were used to assess the agency costs for the first time by Ang et al (2000). In their study they used the ratio of operational costs to yearly sale to measure agency costs. The ratio of operational costs to yearly sale measures how much directors control the company operational costs and used as direct scale for agency costs namely when the ratio is higher the agency costs are higher, too. According to Fleming et al. (2005) the natural logarithm of the variable was used in applying the dependent variable in order to adjust its fluctuations. 


\subsection{Agency theory}

The brokerage relation is contractual by which a group (Possessors) appoints someone (s) as their agent or representative and makes him (her, their) as responsible and officer to do some defined duties in the firm. It is necessary to transfer the power to take decisions in order to conclude contract; in such contract both parties (Representative and possessor) know that each of them wishes for personal gains. Considering the director may work not in line with the possessor's gains and wishes for his (her) own gains (Such as professional security, personal validity, allowances and salary, etc.) such gains may make directors avoid risky operations and then most probably their positions are blemished while they agree with the first result; so the gain is less than the rate expected by the possessors and then it may lead to a contradiction between the shareholders' gains maximization and personal directors' gains known as 'agency problem or question' (Nikoomaram and Banimahd, 2006).

When a company resorts to the lenders to finance the grantors are considered as the possessors who deliver their asset (The lent money) to the company directors and then the latter as the agent(s) use(s) it as the sources. If it is supposed that there is no law and regulations regarding the contract to be concluded between the company directors and grantors, most probably the director tries opportunistically to maximize his(her) own gains (Mashayekh \& Esmaeili, 2006).

Also there is agency relation between the firm grantors and their directors; in this relation it is supposed that the grantor permits the director to benefit from the facilities made available to the firm by the former; in other words, the director is permitted to take decisions regarding sources not belonging to him(her); here maybe the director does not work in line with the grantor's gains so it leads to some problems. This theory plays an important role in defining affirmative theory in accounting. The agency problems lead to non-optimal decisions, improper allocation of the sources and finally the company value decreases (Mashayekh \& Esmaeili, 2006).

One of the mechanisms which is important to transfer duties to directors by possessors is the fiscal statements to be issued by directors. It should be noted that the people in the community inherently try to increase their personal interests and so do the directors who are interested in presenting a favorable image of their firm to the shareholders and other beneficiaries in line with maximizing their personal interests and social welfare and fix their professional position. Here the problem is that the directors' health increase is not necessarily in line with the others' such as shareholders'. In fact, it indicates that the directors' gains are not in line with the beneficiaries' in the firm so in consideration of the contradiction between the directors' and possessors' gains the firms directors may have the motive necessary to manipulate the gain to maximize their own gains (Leventis, 2010).

\subsection{The ratio of fixed assets to total assets (ppe)}

One of the mechanisms to be used to define the companies' financial position is the financial ratios analysis. In fact, the financial ratios reveal important realities in relation to financial operations and condition. When the ratios are calculated the relation between main items of financial statements is more precise. Also they are used to define the strong and weak points of the companies. Of course, the ratio is more significant when they are compared with previous ones of the same company, similar firms or favorable industrial standards.

In present study the fixed assets are used as total ones (PPE) (Lao and Richardson, 1994). The company's noncurrent assets to total assets index indicates how much percent of the assets has been allocated to the fixed asset and long-term investments; in other words, it indicates how much assets ratio to total ones may not change to liquidity in short-tem.

\subsection{The sale ratio to industry (COMP)}

The companies listed in Tehran stock exchange are categorized into different industries. The categorization is done by ISIC method led to separate 36 industries in Tehran stock exchange. The sale ratio to industry is measured by considering a special company sale ratio to the total industry. Tehran stock exchange measures the price index for each industry to be calculated by a formula similar to total price index. In a more general division the companies listed in Tehran stock exchange are divided into two industrial and financial groups including financial intermediary industry and stock exchange (Except financial intermediary) 
companies, respectively. Tehran stock exchange measures the price for both general groups to be issued as financial and industrial indexes and both of them follow total price index scales to design measure and adjust.

\section{The Study history}

Gul et al. (1998) examined the effect of the directors' powers as the agency cost scale on pricing auditing services in Hong Kong. The data were accumulated from the companies listed in Hong Kong stock exchange and the sample included 70 companies. By virtue of above data accumulated by different statistical methods such as regression one it may claim that the agency costs influence pricing auditing services and it is possible to take into account them in pricing auditing services.

Jagannathan and Srinivasan (2000) examined the effect of competition on agency costs in U.S.A.; the agency costs were measured by the assets flow. The data were accumulated from the companies listed in U.S.A. stock exchange and the sample included 165 companies. By virtue of above data different industries were separated by different statistical methods such as regression one so it may claim that the competition in market influences the agency costs reversely.

Grifild (2001) examined the competition effect in product market and agency costs; his sample included 897 European companies in 1980-1996; the agency costs was measured by the ratio of operational costs to sale; the findings indicated that there is a negative and significant relation between the competition in product market and agency costs. Also the ratio of lending from banking system to total debts and ratio of short- term debt to total debts and the number of unbound members of board of directors are the mechanisms decreasing the agency costs.

Leventis and Weetman (2011) examined the relation between the competition intensity in product market and agency cost by analyzing theoretically and regression in 174 companies listed in Athens stock exchange. The auditing fees cost and work hours were used substitution for agency costs and industry sale percent and concentration ratio was used as the competition variables in the product market; the findings indicated that the product market range in actual markets limits have reverse relation with the auditing fees and the supervision decrease is compensated by increasing management' supervision by the competitors.

\section{Hypotheses Development}

The presence and range of the agency costs depends on the nature of supervision (Auditing) costs for nonfinancial gains and financing directors who are able to invest and sustain the risk out of their personal assets. If the supervision costs are zero, naturally the agency ones are zero or if the directors are available enough to possess and direct all companies in an (Competitive or noncompetitive) industry, the agency costs are zero in the industry (Leventis and Weetman, 2011). It is necessary to have ideal conditions to eliminate agency costs completely which are note practically visible; stated findings show that there is no relation between the product market competition and supervision costs because of directional control (Leventis and Weetman, 2011).

In comparison other writers, for example, Baggs and De Bettignies (2007) and Srinvasan and Jagannathan (1999) have found a potential relation between the product market competition and supervision costs. So by virtue of above mentioned cases following hypothesis is proposed:

\section{H1: When the product market competition increases the operational costs efficiency increase, too.}

In line with the study goal we try to find if there is any significant relation between the product market competition and operational costs efficiency; in other words, have the independent variables the potential to describe and define the dependent ones; in line with this in harmonization with Ang et al. (2000), Singh and Davidson(2003), Fleming et al.(2005) and Florakis (2008) the efficiency ratios were namely the ratio of operational costs to the yearly sale was used as the agency costs scales and above hypothesis was defined.

\section{H2: When the product market competition increases the auditing fees decreases.}

Considering the auditing fees is one of the agency costs scales when the product market competition increases the auditing fees decreases. The findings of the hypothesis gained by Weetman et al. (2011) indicate that market competition increase leads to agency cots decrease. Largely in most conditions the competition pressure decreases the prices proposed by producing companies and firms presenting services and the fees $\mathrm{s}$ proposed by auditing organization and trusty auditing firms in Tehran stock exchange were not exception. 


\section{Study method}

The model to be used to test $\mathrm{H} 1$ is as follows:

$O C=b 0+B 1 P P E j+b 2 C P+B 3 C O M P j+B 4 S I Z E j+B 5 C U R R E N T j+B 6 Q U I C K j+B 7$ SUBj+ B8 ROAj+B9 LOSS $j+B 10$ $R E M+B 11 C H A N+B 12 b d+B 13 D E+B 14$ comp2j

In the model the dependent variable is operational costs efficiency. The efficiency ratios were used to assess the agency costs for the first time by Ang et al (2000). In their study they used the ratio of operational costs to yearly sale to measure the agency costs. The ratio of operational costs to yearly sale measures how directors control the company operational costs and is used as the direct scale of agency costs namely when the ratio is higher the agency costs are higher, too.

The model to be used to test $\mathrm{H} 2$ is as follows:

$A F=b 0+B 1 P P E j+b 2 C P+B 3 C O M P 1 j+B 4 S I Z E j+B 5 C U R R E N T j+B 6 Q U I C K j+B 7$ SUBj+ B8 ROAj+B9 LOSS $j+B 10$ $R E M+B 11 C H A N+B 12 b d+B 13 D E+B 14$ comp2j

In the model the dependent variable is auditing services fees. In most studies concerning the auditing fees it is calculated as natural logarithm to be paid as related services to the auditing company during the year (LAF) (Gujarati, 2009).

The used independent variables, auditing organization concentration ratio (Comp1), industry sale ratio (Comp2), the ratio of assets and gross equipments to total assets (PPE), the ratio of sale costs to total sale (cps) and control variables to be assessed include:

DE: The ratio index of book debts value to owners' equity.

SIZE: Company size to be measured by sake logarithm (Sale In).

CURRENT: Current assets ratio gained by dividing current assets by total ones.

QUICK: Speed ratio.

SUB: The companies with subgroups and affiliated groups 1 , otherwise zero.

ROA: The ratio of profit before interest and tax deduction to total assets.

LOSS: If the companies under assessment have sustained loss last year, it is 1 , otherwise zero.

REM: The type of auditing report is 1 , if it is favorable, otherwise zero.

CHAN: Dummy variable: It is 1 , if the company auditor has changed from previous year, otherwise zero. bd: The debt ratio which is gained by dividing short-term debt by the long-term one.

\section{Data analysis}

The descriptive statistics of the study variables are shown in Table 1.

Table 1. The descriptive statistics of the study variables

\begin{tabular}{|c|c|c|c|c|c|}
\hline Statistic & Mean & Middle & Standard deviation & Minimum & Maximum \\
\hline auditing fees & $5 / 555$ & $5 / 519$ & $0 / 675$ & $2 / 3$ & $0 / 24$ \\
\hline $\begin{array}{c}\text { operational costs } \\
\text { efficiency }\end{array}$ & $0 / 188$ & $0 / 165$ & $0 / 179$ & $0 / 41$ & $0 / .89$ \\
\hline $\begin{array}{c}\text { industry sale ratio } \\
\text { index }\end{array}$ & $0 / 097$ & $0 / 026$ & $0 / 189$ & $0 / 05$ & $0 / .64$ \\
\hline $\begin{array}{c}\text { the ratio of assets } \\
\text { and equipments } \\
\text { to total assets }\end{array}$ & $0 / 381$ & $0 / 345$ & $0 / 245$ & $0 / 006$ & $0 / .87$ \\
\hline $\begin{array}{c}\text { the ratio of } \\
\text { distribution and } \\
\text { sale costs to total } \\
\text { sale }\end{array}$ & $0 / 101$ & $0 / 034$ & $0 / 204$ & $0 / 000$ & $19 / 48$ \\
\hline $\begin{array}{c}\text { the ratio of book } \\
\text { debts value to } \\
\text { owners' equity }\end{array}$ & 2.6 & $1 / 934$ & $4 / 14$ & $9 / 510$ & \\
\hline
\end{tabular}


International Journal of Academic Research in Accounting, Finance and Management Sciences Vol. 3 (3), pp. 95-104, @ 2013 HRMARS

\begin{tabular}{|c|c|c|c|c|c|}
\hline Statistic & Mean & Middle & Standard deviation & Minimum & Maximum \\
\hline company size & $12 / 669$ & $12 / .46$ & $1 / 407$ & $9 / 16$ & $17 / 7$ \\
\hline $\begin{array}{c}\text { the ratio of } \\
\text { current assets to } \\
\text { total assets }\end{array}$ & $1 / 259$ & $1 / 16$ & $0 / .621$ & 0/014 & $3 / 53$ \\
\hline speed ratio & $0 / 731$ & $0 / 683$ & $0 / 438$ & $0 / 006$ & $2 / 02$ \\
\hline $\begin{array}{l}\text { the companies } \\
\text { with subgroups } \\
\text { and affiliated } \\
\text { groups }\end{array}$ & $0 / 161$ & $0 / 000$ & $0 / 368$ & $0 / 000$ & $1 / 000$ \\
\hline $\begin{array}{l}\text { the ratio of profit } \\
\text { before interest } \\
\text { and tax deduction } \\
\text { to total assets }\end{array}$ & $0 / 169$ & $0 / 128$ & $0 / 161$ & $0 / 150-$ & $0 / 65$ \\
\hline $\begin{array}{c}\text { companies with } \\
\text { loss in previous } \\
\text { year }\end{array}$ & $0 / 122$ & $0 / 000$ & $0 / 328$ & $0 / 000$ & $1 / 000$ \\
\hline $\begin{array}{c}\text { the ratio of } \\
\text { short-term debt } \\
\text { to the long-term } \\
\text { one }\end{array}$ & $0 / 862$ & $0 / 928$ & $0 / 158$ & $0 / 22$ & $1 / 000$ \\
\hline the auditor's view & $0 / 33$ & $0 / 000$ & $0 / 471$ & $0 / 000$ & $1 / 000$ \\
\hline auditor change & $0 / 139$ & $0 / 000$ & $0 / 347$ & $0 / 000$ & $1 / 000$ \\
\hline $\begin{array}{c}\text { auditing } \\
\text { organization } \\
\text { concentration } \\
\text { ratio }\end{array}$ & $0 / 279$ & $0 / 000$ & $0 / 449$ & $0 / 000$ & $1 / 000$ \\
\hline
\end{tabular}

Having examined the descriptive statistics of the study variables the dependent variables normality (Agency costs variables) by Kolmogoroff and Smirnoff test and normal distribution figure. The findings resulted from Kolmogoroff and Smirnoff test are shown in Table 2; as you see the test statistic and significance related to all agency costs scales are more than 0.05 indicating the examined variables are normal.

Table 2. The findings resulted from Kolmogoroff and Smirnoff test

\begin{tabular}{|c|c|c|c|}
\hline Dependent variables & Number of observations & Test statistic & Significance \\
\hline auditing cost & 336 & $1 / 187$ & $0 / 12$ \\
\hline operational costs efficiency & 336 & $1 / 401$ & $0 / 064$ \\
\hline
\end{tabular}

The findings resulted from testing the study hypotheses:

$\mathrm{H} 1$ : The study variables were used to test $\mathrm{H} 1$; related findings and model estimation are shown in Tables 3 and 4.

Table 3. The findings from examining generally the model-H1

\begin{tabular}{|c|c|c|c|c|}
\hline$R$ & $R^{2}$ & statistic ' $F$ ' & $\begin{array}{c}\text { statistic ' } F \text { ' } \\
\text { significance }\end{array}$ & $\begin{array}{c}\text { Durbin-Watson } \\
\text { statistic }\end{array}$ \\
\hline $0 / 619$ & $0 / 602$ & $36 / 39$ & $0 / 000$ & $1 / 87$ \\
\hline
\end{tabular}

As you see in Table 3 the statistic ' $F$ ' amount and related significance indicate that the estimated regression model is generally significant; in the model the definition coefficient is 0.619 namely 61.90 percent of the dependent variable changes are explicable by independent and control variables; the findings were gained from examining autocorrelation of error terms by Durbin-Watson statistic and considering the gained statistic is in the 1.5-2.5 range there is no autocorrelation between the model errors.

The findings resulted from examining the model variables coefficients are shown in Table 4. As you see in Table 4 the coefficient, statistic' $t$ ' and the significance indicate related to the study independent variable indicate that there is a positive and significant relation between the competition in product market and operational costs efficiency; in other words, when the competition increased between the examined companies in product market the ratio of operational costs to the sale increase in the companies, too. So H1 is 
accepted in confidence rate of 95 percent. Also the coefficients, statistic ' $t$ ' and significance related to the control variables indicate that the ratio of book debt value to the owners' equity, company size, the ratio of current assets to total ones and dummy variable of the companies with subgroups and affiliated groups, the ratio of profit before interest and tax deduction to total assets and dummy variable, type of auditor's view have negative and significant relation and the speed ratio has positive and significant relation with operational costs ratio to the sale; however, the ratio of short-term debt to the long-term one and dummy variables namely auditor change and companies with loss in previous year had no significant effect on the ratio of operational costs to the sale.

Table 4. Findings resulted from examining partial model coefficients-H1

\begin{tabular}{|c|c|c|c|c|}
\hline Statistic & Coefficients & Statistic ' $T$ ' & Standard deviation & Significance \\
\hline stable rate & $0 / 03$ & $0 / 574$ & $0 / 052$ & $0 / 567$ \\
\hline $\begin{array}{c}\text { the ratio of assets and } \\
\text { equipments to total } \\
\text { assets }\end{array}$ & 0/059 & $2 / 786$ & $0 / 021$ & 0/006 \\
\hline $\begin{array}{c}\text { the ratio of } \\
\text { distribution and sale } \\
\text { costs to total sale }\end{array}$ & $0 / 135$ & $2 / 782$ & 0/019 & 0/016 \\
\hline industry sale ratio & $0 / 042$ & $4 / 901$ & $0 / 009$ & $0 / 000$ \\
\hline $\begin{array}{l}\text { the ratio of book } \\
\text { debts value to } \\
\text { owners' equity }\end{array}$ & $-0 / 16$ & $-3 / 585$ & 0/001 & $0 / 000$ \\
\hline company size & $-0 / 274$ & $-2 / 902$ & $0 / 003$ & $0 / 008$ \\
\hline $\begin{array}{l}\text { the ratio of current } \\
\text { assets to total assets }\end{array}$ & $-0 / 024$ & $-2 / 677$ & $0 / 009$ & $0 / 008$ \\
\hline speed ratio & $0 / 057$ & $6 / 042$ & $0 / 009$ & $0 / 000$ \\
\hline $\begin{array}{l}\text { the companies with } \\
\text { subgroups and } \\
\text { affiliated groups }\end{array}$ & $-0 / 013$ & $-1 / 162$ & $0 / 011$ & $0 / 246$ \\
\hline $\begin{array}{c}\text { the ratio of profit } \\
\text { before interest and } \\
\text { tax deduction to total } \\
\text { assets }\end{array}$ & $-0 / 192$ & $-5 / 721$ & $0 / 034$ & $0 / 000$ \\
\hline $\begin{array}{c}\text { companies with loss } \\
\text { in previous year }\end{array}$ & $-0 / 015$ & $-1 / 191$ & $0 / 012$ & $0 / 234$ \\
\hline $\begin{array}{l}\text { the ratio of short- } \\
\text { term debt to the } \\
\text { long-term one }\end{array}$ & 0/083 & $1 / 095$ & $0 / 027$ & 0/092 \\
\hline the auditor's view & $-0 / 148$ & $-2 / 725$ & $0 / 009$ & $0 / 085$ \\
\hline auditor change & $-0 / 006$ & $-0 / 512$ & $0 / 012$ & $0 / 609$ \\
\hline auditing size ratio & $0 / 147$ & $8 / 319$ & $0 / 018$ & $0 / 000$ \\
\hline
\end{tabular}

$\mathrm{H} 2$ : The study variables were used to test $\mathrm{H} 2$; related findings and model estimation are shown in Tables 5 and 6.

Table 5. The findings from examining generally the model- $\mathrm{H} 2$

\begin{tabular}{|c|c|c|c|c|}
\hline$R$ & $R^{2}$ & statistic ' $F$ ' & $\begin{array}{c}\text { statistic ' } F \text { ' } \\
\text { significance }\end{array}$ & $\begin{array}{c}\text { Durbin-Watson } \\
\text { statistic }\end{array}$ \\
\hline $0 / 555$ & $0 / 536$ & $27 / 932$ & $0 / 000$ & $1 / 939$ \\
\hline
\end{tabular}

As you see in Table 5 the statistic ' $F$ ' amount and related significance indicate that the estimated regression model is generally significant; also the definition coefficient is 0.555 namely 55.5 percent of the dependent variable changes are explicable by independent and control variables; the findings were gained from examining autocorrelation of error terms by Durbin-Watson statistic and considering the gained statistic is in the 1.5-2.5 range there is no autocorrelation between the model errors. 
The findings resulted from examining the model variables coefficients are shown in Table 6 . As you see in Table 6 the coefficient, statistic ' $t$ ' and the significance indicate related to the study independent variable indicate that there is a negative and significant relation between the competition in product market and auditing fees; in other words, when the competition increased in product market the auditing fees decreases in the companies so $\mathrm{H} 2$ is accepted in confidence rate of 95 percent. Also the coefficients, statistic ' $\mathrm{t}$ ' and significance related to the control variables indicate that the speed ratio and auditor change have significant and negative relation with the ratio of book debts value to the owners' equity, company size, the ratio of current assets to total ones, the ratio of profit before interest and tax deduction to total assets and type of auditor's view have positive and significant relation with auditing fees; however, the companies with subgroups and affiliated groups, companies with loss in previous year and the ratio of short-term debt to the long-term one had no significant effect on the auditing fees.

Table 6. The findings from examining the partial model coefficients- $\mathrm{H} 2$

\begin{tabular}{|c|c|c|c|c|}
\hline Statistic & Coefficients & Statistic ' $T$ ' & Standard deviation & Significance \\
\hline stable rate & $5 / 246$ & $13 / 852$ & $0 / 379$ & $0 / 000$ \\
\hline $\begin{array}{c}\text { the ratio of assets and } \\
\text { equipments to total } \\
\text { assets }\end{array}$ & $-0 / 483$ & $-3 / 094$ & $0 / 156$ & $0 / 002$ \\
\hline $\begin{array}{c}\text { the ratio of } \\
\text { distribution and sale } \\
\text { costs to total sale }\end{array}$ & $-0 / 64$ & $-4 / 142$ & $0 / 155$ & $0 / 000$ \\
\hline industry sale ratio & $-0 / 115$ & $-2 / 842$ & $0 / 063$ & $0 / 016$ \\
\hline $\begin{array}{l}\text { the ratio of book } \\
\text { debts value to } \\
\text { owners' equity }\end{array}$ & $0 / 104$ & $2 / 507$ & $0 / 008$ & $0 / 022$ \\
\hline company size & $0 / 76$ & $3 / 435$ & $0 / 022$ & $0 / 001$ \\
\hline $\begin{array}{l}\text { the ratio of current } \\
\text { assets to total assets }\end{array}$ & $0 / 17$ & $2 / 57$ & $0 / 066$ & $0 / 011$ \\
\hline speed ratio & $-0 / 313$ & $-4 / 533$ & $0 / 069$ & $0 / 000$ \\
\hline $\begin{array}{l}\text { the companies with } \\
\text { subgroups and } \\
\text { affiliated groups }\end{array}$ & $0 / 127$ & $1 / 571$ & $0 / 081$ & $0 / 117$ \\
\hline $\begin{array}{c}\text { the ratio of profit } \\
\text { before interest and } \\
\text { tax deduction to total } \\
\text { assets }\end{array}$ & $0 / 704$ & $2 / 862$ & $0 / 246$ & $0 / 004$ \\
\hline $\begin{array}{l}\text { companies with loss } \\
\text { in previous year }\end{array}$ & 0/03 & $1 / 327$ & 0/089 & $0 / 198$ \\
\hline $\begin{array}{l}\text { the ratio of short- } \\
\text { term debt to the } \\
\text { long-term one }\end{array}$ & $-0 / 052$ & $-1 / 61$ & $0 / 198$ & $0 / 295$ \\
\hline the auditor's view & $0 / 221$ & $3 / 074$ & $0 / 063$ & $0 / 001$ \\
\hline auditor change & $-0 / 367$ & $-4 / 553$ & $0 / 081$ & $0 / 000$ \\
\hline auditing size ratio & $-0 / 497$ & $-3 / 514$ & $0 / 141$ & $0 / 001$ \\
\hline
\end{tabular}

\section{Conclusions}

The findings from examining the model variables coefficients indicate that there is a significant and positive relation between the ratio of auditing organization concentration and operational costs efficiency; in other words, when the competition increases between the companies in the product market the ratio of operational costs to the sale increases in the companies. Also the company size and the ratio of short-term debt to the long-term one have no significant effect on the ratio of operational costs to the sale. In comparison as mentioned in the review history other writers such as Jagannathan and Srinivasan (1991), GalOr (2007), Baggs and De Bettignies (2007), Taylor et al. (1989) used the operational costs efficiency and assets flow as the substitutions for the agency cost and found a potential positive relation between the competition intensity in market and agency costs similar to the findings from next study. 
Jensen and Meckling claimed that the competition in the product market does not depend on the agency costs, but in another place in economic science history the theoretical and experimental study shows that the competition in the product market decreases the agency costs sustained by the companies through decreasing the auditing fees. We examined the relation between the competition in the product market and auditing fees as a sample of agency cost; the findings resulted from examining the model variable coefficients indicate that there is a negative and significant relation between the competition in the product market and the auditing fees; in other words, when the competition increases in the examined companies the product market the auditing fees decreases in the companies. So the study hypothesis is accepted so we conclude that the competitive pressures in the product market decrease the auditing wags as an agency cost and then the shareholders decrease the costs concerning supervising agencies.

However, the stated findings indicate there is a negative and significant relation between the competition in the product market and agency costs because of directional control. In comparison as mentioned in the review history other writers such as Weetman et al.(2011) and Gul et al. (1998) assessed the auditing fees as the agency costs scale and their findings were in harmonization with the findings from next study and Gal-Or (2007) observed a reverse relation in the findings and Baggs and De Bettignies (2007) concluded that there is no relation between the competition in the product market and agency costs.

\section{References}

1. Mashayesh, Sh. \& Esmaeili, M., 2006, 'Examining The Relation Between The Profit Quality \& Some Aspects Of Strategic Principles In The Companies Listed In Tehran Stock Exchange', Accounting \& Auditing Examinations Journal, No. 45, pp. $25-44$.

2. Nikkomaram, Hashem \& Bahman, Banimahd (2006), 'A Glance At Accounting Affirmative Studies ', Accountant Journal, No. 178, pp. $50-55$.

3. Ang, J. Cole, R. and Lin, J., 2000, Agency Costs and Ownership Structure. The Journal of Finance, Vol. 55 , No. 1, pp. 81-106.

4. Chancy, P.K \& D.C, Jeter and P.E, Shaw. (2003). "The impact on the market for audit sevices of aggressive competition by auditors". Journal of Accounting and public policy (November-December). pp487516.

5. Eilifsen, A., Knechel, R., \& Wallage, P. (2001). Application of the business risk audit model: a field study. Accounting Horizons, 15(3), 193-207.

6. Fama, E.F., 1980, Agency problems and the theory of the firm, Journal of Political Economy, 88, pp. 288-307.

7. Friedman, M. (13 September 1970). A Friedman doctrine - The social responsibility of business is to increase its profits. New York Times Magazine, 32ff.

8. Gal-Or, E. (1997). Multiprincipal agency relationships as implied by product market competition. Journal of Economics \& Management Strategy, 6(2).

9. Gul, Ferdinand A., J. Tsui, Charles J. P. Chen. (1998). "Agency Costs and Audit Pricing: Evidence on Discretionary Accruals", Working paper, City University of Hong Kong.

10. Harlow, W.V. and John S. Howe (1993). "Leveraged Buyout and Insider Nontrading." Financial Management, Vol. 22, No. 1, pp. 109-118.

11. Healy ,P.M \& K.G, Palepu . (2003). "How the Quest for efficiency corroded the market". Haevard business Review (July). pp 76- 85 .

12. Jagannathan, R., \& Srinivasan, S. B. (1999). Does product market competition reduce agency costs? North American Journal of Economics and Finance, 15(2).

13. Jelinek, K. and Stuerke, P. S., 2009, The Nonlinear Relation Between Agency Costs and Managerial Equity Ownership, Evidence of Decreasing Benefits of Increasing Ownership, International Journal of Managerial Finance, Vol. 5, No. 2, pp. 156-178.

14. Jensen \&Meckling, W.(2005). "Theory of the firm: Managerial behavior, agency costs, and capital structure", Journal of Financial Economics, 3, pp. 305-360.

15. Jensen, M. C., \& Meckling, W. (1976). Theory of the firm: managerial behaviour, agency costs and ownership structure. Journal of Financial Economics, 3. 
16. Karim, W. A. K. M., \& Moizer, P. (1996). Determinants of audit fees in Bangladesh. The International Journal of Accounting, 31(4), 497-509.

17. Karuna, C. (2007). Industry product market competition and managerial incentives. Journal of Accounting and Economics, 43, 275-297.

18. R. P., Mialon, H. M., \& Williams, M. A. (2004). What is a barrier to entry? The American Economic Review, 94(2), 461-465.

19. Namazi, M. (1985). "Theoretical Developments of Principal - Agent Employment Contract In Accounting: the State of the Art", Journal of Accounting Literature, 4, pp. 113-163.

20. Pepall, L., Richards, D., \& Norman, G. (2008). Industrial organization: Contemporary theory and empirical applications. Blackwell.

21. Simunic, D. (1984). "Auditing, consulting, and auditor independence". Journal of Accounting Research, Vol. 22.

22. Simunic, D.A. (1980). "The Pricing of Audit Services: Theory and Evidence", Journal of Accounting research, spring, pp. 161-190.

23. Simunic, D.A., and M.T. Stein. (1996). "The Impact of Litigation Risk on Audit Pricing: A Review of the Economics and the Evidence", Auditing: A Journal of Practice \& Theory, Supplement, pp. 119-134.

24. Sunder, Shyam, (1997). Theory of Accounting \& Control. USA, Cincinnati: Southwest College.

25. Taylor, Mark h. \& Daniel T. Simon. (1999). "Determinants of Audit Fees: The Importance of Litigation, Disclosure and Regulatory Burdens in Audit Engagements in 20 Countries", The International Journal of Accounting, Vol. 34, No. 3, pp. 375- 388

26. Zeff , S. (2003). "How the U.S. accountancy profession got where it is today: part II". Accounting Horizons. 17(4):267-286. 